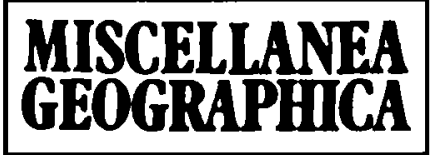

WARSZAWA 1992 Vol. 5

\title{
Krzysztof Olszewski
}

\section{MACROTYPES OF ATMOSPHERIC CIRCULATION AND DIURNAL COURSE OF THE AIR TEMPERATURE}

The circulation factors play an essential role in shaping weather and climatic conditions in the middle latitudes because this zone is marked by the greatest atmospheric variability (a succession of cyclones and anticyclones). The effect of atmospheric circulation on climate has been known for a long time. Likewise, the investigation of the circulation processes and their influence on shaping climatic conditions has been conducted for decades. The tendencies of changes in occurrence of the given type of circulation have been investigated, and values of climatic elements in the particular types of circulation have been defined. Many papers have been written on the subject but they are less important works. Among all the meteorological elements, most attention has been paid to the effect of atmospheric circulation on the air temperature. Polish works include i.a. Lityński (1969), Kossowska-Cezak (1982), Kożuchowski (1989), and Kuziemski (1970).

The aim of this paper is to study a diurnal course of the air temperature according to the macrotypes of atmospheric circulation. For the purpose of this paper use was made of the data of the every-hour observations carried out at the meteorological station of Warszawa-Okecie in the years 1956-1960. To define the types of circulation, the Osuchowska-Klein Catalogue (1978) was used and the types of circulations of very great and great similarity to the model type were taken into account. On this basis, the division was made of circulation macrotypes (Osuchowska-Klein 1973). The twofold system of grouping was applied: in the first group, the direction of inflow of the air mass (macrotype of the eastern and western circulation) was essential; in the other, the baric configuration in which the given mass inflows (macrotype of the cyclonic and anticyclonic circulations) was the most important one. Such generalizations are of practical significance for the analysis of climatological features of the circulation types and for preparation of the weather forecast, particularly a long-term one, as it is an essential issue to be able to forecast at least one of the features of the circulation type. On the days of the macrotypes thus defined, the average diurnal course of the air temperature was calculated by the method of harmonic analysis. 
MACROTYPES OF THE EASTERN AND WESTERN CIRCULATIONS

All types of circulation have been included here: those characterized by the inflow of air masses from the western sector (W - "maritime") situated to the West from the North-South direction, and those from the eastern sector (E "continental"), situated to the East from this border (Osuchowska-Klein 1973).

The greatest differentiation of the diurnal course of the air temperature in the macrotype of eastern/western circulation manifests itself in the cooler season of the year. Higher mean daily temperature (even about $10^{\circ}$ centigrade) is then connected with the circulation from the western sector (Fig.1). The character of the diurnal changes is similar. The daily amplitude has a similar value (Table 1); only in the macrotype of the eastern circulation the minimum air temperature occurs 1-2 hours later.

In the warmer season of the year, from May to August, the differentiation of the diurnal course in these two macrotypes of circulation is negligible. Differences in the mean daily temperature between these types of circulation do not exceed $2^{\circ} \mathrm{C}$. The greater differentiation could be observed around noon, when the higher temperature is noted with the inflow of the air masses of the eastern circulation. At night, this direction of inflow of the air can be of a slightly lower temperature. It is probably bound up with the differentiation of cloudiness in the air coming from the "continental" eastern sector and "maritime" western sector.

A comparison of the diurnal course of the air temperature - with varying macrotypes of the directions of circulation - permits a conclusion that they do not play a decisive role in the warm season of the year. More essential differences can be observed from November till March, when the direction of inflow of the air masses plays a principal part in shaping the thermal conditions of the given area.

\section{MACROTYPES OF THE CYCLONIC AND ANTICYCLONIC CIRCULATION}

As a basis for distinguishing the circulation macrotypes, the cyclonic and anticyclonic character of the particular circulation types has been assumed (Osuchowska-Klein 1973). Thus, two macrotypes were obtained: cyclonic circulation ( $\mathrm{C}$ - low pressure) and anticyclonic circulation ( $\mathrm{A}-$ high pressure). Differentiation of the air temperature according to the baric configuration shows itself clearly from October till March, that is in the cool season of the year (Fig.2). In this season the mean daily area temperatures range from -0.2 to $10.0^{\circ} \mathrm{C}$ in the cyclonic macrotype, and from -6.0 to $8.0^{\circ} \mathrm{C}$ in the anticyclonic one. In the particular months, differences in temperature between these macrotypes do not exceed $6^{\circ} \mathrm{C}$ (Table 1). Yet the character of diurnal changes is similar, which is illustrated by the similar daily amplitude: in both macrotypes it ranges between 2 and 8 degrees. 

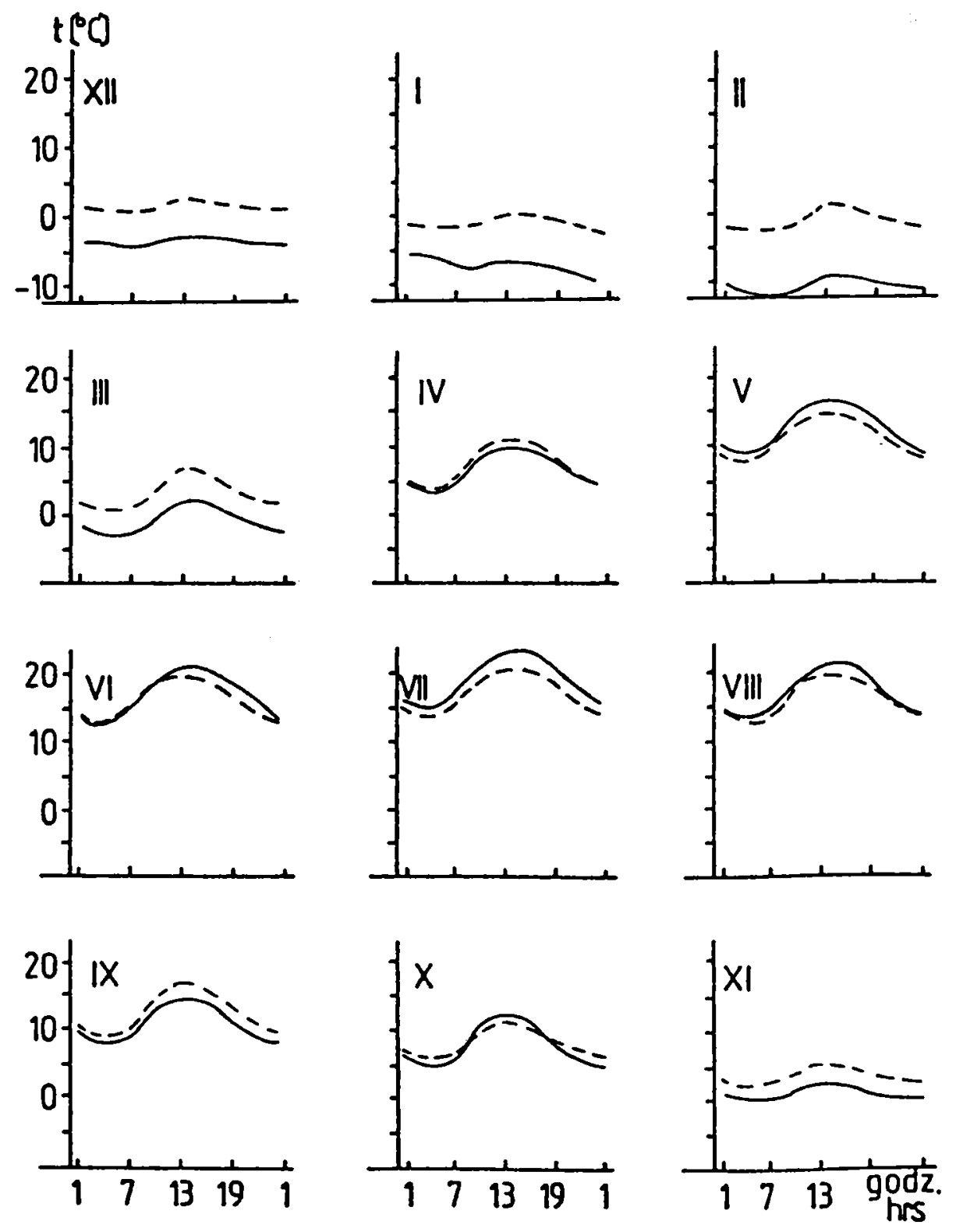

Fig. 1.Sinusoids of diumal course of the air temperature in eastem circulation macrotypes (Warsaw 1956-1960)

In the warmer season of the year (April - September), the type of baric configuration does not play such a significant role in shaping diurnal changes of the air temperature (Fig.2). From May to August, the slightly higher air temperature 
can be observed in the anticyclonic configurations. Their mean daily value and extreme temperatures are around $1-3^{\circ} \mathrm{C}$ higher than in the cyclonic ones (Table 1). In April and September the mean daily air temperature in both macrotypes is similar but the low pressure configuration is characterized by warmer nights and cooler days than the high pressure. The reason for such changes in temperature is probably cloudiness; it is usually smaller in the anticyclones than in the cyclones. It provides more favourable conditions for a more intensive inflow of the sun radiation during the day but also for the increased outflow of terrestial radiation at night.

Table 1

Mean air temperature $\left({ }^{\circ} \mathrm{C}\right.$ ) in macritypes of circulation (Warsaw 1956-1960)

\begin{tabular}{|c|c|c|c|c|c|c|c|c|c|c|}
\hline month & type & daily & $\min$. & $\max$. & ampl. & type & daily & $\min$. & $\max$. & ampl. \\
\hline \multirow[t]{2}{*}{ I } & $w$ & -0.7 & -1.6 & 0.7 & 2.3 & C & -0.5 & -1.1 & 0.8 & 1.9 \\
\hline & E & -7.1 & -8.5 & -5.6 & 2.9 & A & -3.5 & -4.3 & -2.3 & 2.0 \\
\hline \multirow[t]{2}{*}{ II } & $\mathrm{W}$ & -0.4 & -2.1 & 1.9 & 4.0 & C & -0.2 & -1.4 & 1.8 & 3.2 \\
\hline & E & -10.4 & -11.9 & -8.7 & 3.2 & A & -6.0 & -7.8 & -3.7 & 4.1 \\
\hline \multirow[t]{2}{*}{ III } & $\mathrm{W}$ & 3.6 & 0.7 & 7.3 & 6.6 & C & 3.0 & 0.9 & 5.8 & 4.9 \\
\hline & $\mathrm{E}$ & -0.3 & -3.1 & 2.9 & 6.0 & A & -0.2 & -3.4 & 3.4 & 6.8 \\
\hline \multirow[t]{2}{*}{ IV } & W & 7.3 & 3.6 & 10.8 & 7.2 & $\mathrm{C}$ & 7.0 & 3.9 & 10.2 & 6.3 \\
\hline & $\mathrm{E}$ & 6.8 & 3.2 & 10.5 & 7.3 & $\mathrm{~A}$ & 7.0 & 2.9 & 11.1 & 8.2 \\
\hline \multirow[t]{2}{*}{ v } & $\bar{w}$ & 11.7 & 7.9 & 15.6 & 7.7 & C & 10.6 & 7.9 & 14.0 & 6.1 \\
\hline & E & 12.9 & 8.5 & 16.9 & 8.4 & $\mathrm{~A}$ & 12.9 & 8.3 & 17.0 & 8.7 \\
\hline \multirow[t]{2}{*}{ VI } & w & 16.0 & 12.3 & 19.5 & 7.2 & C & 16.2 & 13.1 & 19.3 & 6.2 \\
\hline & E & 16.7 & 12.0 & 21.2 & 9.2 & A & 16.3 & 11.5 & 21.0 & 9.5 \\
\hline \multirow[t]{2}{*}{ VII } & $w$ & 17.8 & 14.1 & 21.3 & 7.2 & C & 17.8 & 14.0 & 21.4 & 7.4 \\
\hline & $E$ & 19.9 & 15.4 & 24.3 & 8.9 & $\mathrm{~A}$ & 18.8 & 15.0 & 22.9 & 7.9 \\
\hline \multirow[t]{2}{*}{ VIII } & $w$ & 16.8 & 12.7 & 20.7 & 8.0 & $\mathrm{C}$ & 16.3 & 12.7 & 19.8 & 7.1 \\
\hline & $\mathrm{E}$ & 17.2 & 13.0 & 21.6 & 8.6 & $\mathrm{~A}$ & 17.8 & 12.9 & 22.6 & 9.7 \\
\hline \multirow[t]{2}{*}{ IX } & w & 12.7 & 8.8 & 17.0 & 8.2 & C & 12.1 & 9.5 & 15.4 & 5.9 \\
\hline & E & 11.1 & 7.5 & 15.5 & 8.0 & $\mathrm{~A}$ & 12.0 & 7.5 & 17.0 & 9.5 \\
\hline \multirow[t]{2}{*}{$x$} & w & 8.6 & 6.2 & 11.9 & 5.7 & $c$ & 9.6 & 7.3 & 12.9 & 5.6 \\
\hline & $\mathrm{E}$ & 8.2 & 4.6 & 13.0 & 8.4 & A & 7.7 & 4.6 & 11.8 & 7.2 \\
\hline \multirow[t]{2}{*}{ XI } & $w$ & 4.0 & 2.8 & 5.9 & 3.1 & C & 5.2 & 3.9 & 7.7 & 3.8 \\
\hline & $\mathrm{E}$ & 1.3 & 0.4 & 1.8 & 1.4 & $\mathrm{~A}$ & 1.2 & 0.3 & 2.4 & 2.1 \\
\hline \multirow[t]{2}{*}{ XII } & W & 1.8 & 1.0 & 3.0 & 2.0 & C & 2.2 & 1.4 & 3.4 & 2.0 \\
\hline & $\mathrm{E}$ & -3.1 & -3.9 & -3.2 & 0.7 & A & -2.7 & -3.6 & -1.8 & 1.8 \\
\hline
\end{tabular}

Macrotype of circulation: W - westem; E - eastem; C - cyclonic; A - anticyclonic

The analysis of the diurnal changes of the air temperature according to the atmospheric circulation macrotype, related to the direction of the inflow of air masses or to the baric configuration, permits a conclusion that the most sig- 

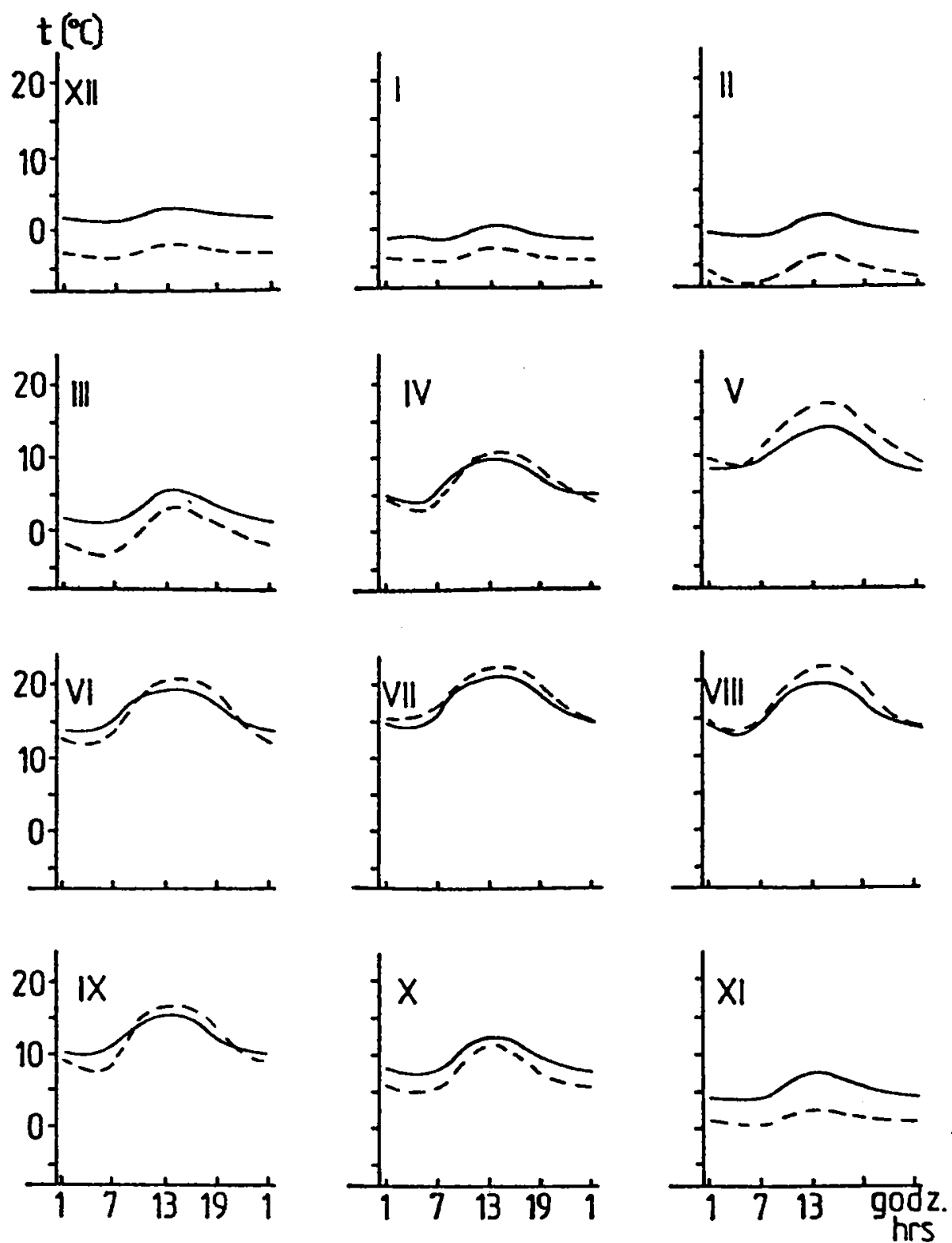

Fig. 2. Sinusoids of diumal course of the air temperature in cyclonic $(\longrightarrow$ and anticyclonic ( - - - ) circulation macrotypes (Warsaw 1956-1960)

nificant differences occur in the cool season of the year. The greatest differentiation among various types of circulation can be observed in this season; the summer season is characterized by smaller mutual differences. A comparison of these 
differences allows us to state that in the extremum seasons, i.e. in winter (January, February) and in summer (June, July) the greater discrepancies in the air temperature are observed between macrotypes linked with the direction of inflow of the air masses than with a baric configuration. This could mean that in these seasons a greater role in shaping diurnal temperature changes is played by the direction of advection than by a baric configuration in which the air mass flows over the given area. The results can be a useful tool in forecasting thermal conditions in the case of definition of the occurrence of the given macrotype of atmospheric circulation.

\section{REFERENCES}

Koss owska-Cezak U., 1982, "Duże zmiany temperatury z dnia na dzień w Polsce" (The large interdiurnal variations of temperature in Poland), Przeglad Geofizyczny, Vol. 27, Nos. 3-4.

Kożuch owski K., 1989, "Makrotypy ogólnej curkulacji atmosfery a temperatura w Polsce" (Hemispheric circulation patterns and air temperature in Poland), Przeglad Geofizyczny, Vol. 34, No. 4.

K uzi e m ski J., 1970, "Wpływ adwekcji na rozklad temperatury powietrza w Polsce" (The impact of advection on the distribution of the air temperature over Poland), Prace PIHM, No. 100.

Li ty ński J., 1969, "Liczbowa klasyfikacja typów cyrkulacji i typów pogody dla Polski (A number classification of the circulation and weather types for Poland), Prace PIHM, No. 97.

O such owska-Klein B., 1978, "Analiza rocznych przebiegów częstości występowania makrotypów cyrkulacji atmosferycznej" (Analysis of the annual course of the frequency of occurrence of the atmospheric circulation macrotypes), Przeglad Geofizyczny Vol. 18, Nos. 3-4.

O s u c h ow s ka - K l e in B., 1978, Katalog typów cyrkulacji atmosferycznej (The Catalogue of the Atmospheric Circulation Types), WKit. Warszawa. 